IIUM JOURNAL OF EDUCATIONAL STUdies, 3:2 (2015) 19-39

Copyright (C) IIUM Press

ISSN: 2289-8085

\title{
Gender Equality and the Participation of Muslim Women in Education and Work: A Critical Analysis
}

\section{Fatmir Shehu, ${ }^{1}$ Bukuri Zejno²}

\begin{abstract}
Most of today's writings on women tend to fit them within the frame of discrimination, where they are presented as victims of a male dominated society. Voices of women's rights proponents are raised to promote gender equality in every aspect of life. However, is that what our society should aim for and to what extent should it carry out this quest? Taking a theoretical approach, this paper looks at women both in educational and work environments. An Islamic perspective is employed to evaluate the general issues throughout the paper, specifically the concept of gender equality. Special reference has been made to selected Qur'anic verses and the Prophetic sayings (Ahadith) dealing with women's issues. The descriptive and analytical methods have been utilized through the entire discussion. This study concludes that problems faced by contemporary women can be solved by referring to the Divine Word of Allah (s.w.t.), the Qur'an and the Prophetic Sunnah, as well as the DivineOriented traditions.
\end{abstract}

Key Words: Women, Islamic education, gender equality, religion, Qur'Én, Sunnah, feminist movement.

\section{Introduction}

During the past few decades, a considerable number of writings, conferences, and talks have addressed the issue of women and their discrimination in a male dominated society, so much so, that everything written about women automatically leads the thoughts and expectations towards this issue. While this might be true for certain countries, where

1 Assistant Professor, Department of Usuluddin and Comparative Religion, Kulliyyah of Islamic Revealed Knowledge and Human Sciences, International Islamic University Malaysia. E-Mail: fatmir@iium.edu.my 2Doctor of Philosophy (Education), Institute of Education, International Islamic University Malaysia. E-Mail: bukurialb@gmail.com 
women do not enjoy many rights, including the rights to education and employment, the quest for gender equality in every aspect continues to be voiced out even in developed countries. It is often overdone to the extent that it even makes many women think: "Is this what I really want?"; or, "Is this the level where I want a certain issue to reach?"; or, "Do these goals represent me?"; or "Is this the woman I want to be?"

Even when recognition is given to the achievements and improvements in the status of women, a "but - statement" always follows, indicating that the progress made it is never enough. The Beijing Declaration states in one of its points:

We, the Governments participating in the Fourth World
Conference on Women)... Recognize that the status of
women has advanced in some important respects in the
past decade but that progress has been uneven, inequalities
between women and men have persisted and major obstacles
remain...(United Nations, 1995, p. 2)

Moreover, whenever examples are given to illustrate the issue of women's discrimination, most Western writers, highlight the country or region that is Muslim, directly or indirectly pointing to Islam as being a religion that oppresses and discriminates women. For people who have a very superficial knowledge about Islam, the first thing they notice is that the real oppression of women lies in any other system or way of life that does not comply with Islam. Confusing Islam with the culture of some societies and being indifferent of the political agendas enforced to these societies would not be a wise attempt for anybody who can produce any piece of writing, what more for somebody who claims it to be a scholarly work.

What stands behind this misconception is not only ignorance but the fact that interpretations are made without taking into consideration the worldview upon which the evaluation criteria are based. Certain practices and policies of the Muslim civilization and culture are judged by most Western publicists "on the basis of principles and ideas prevailing in the Western world...Non Western cultures are judged according to criteria which are not theirs," (Baeck, 2004). As such, judging the Muslim women based on criteria that do not belong to the Muslim culture would be unethical and unjust. 
Josh Cerreti (2012), a feminist, anti-racist, anti-militarist activist and scholar, has mentioned in one of his writings that most of the Westerners look at the Muslim women from the Western eyes. In the view of Fedwa Malti-Douglas (1991, p. 3), "Women and their role become a stick with which the West can beat the East." Also, Joanna Francis (2013), who is a writer and journalist from the United States of America, in one of her writings has confessed the following:

We Western women have been brainwashed into thinking that you Muslim Women are oppressed. But truly, we are the ones who are oppressed, slaves to fashions that degrade us, obsessed with our weight, begging for love from men who do not want to grow up. Deep down inside, we know that we have been cheated. We secretly admire and envy you. Although some of us will not admit it...We Christian women need to see what life is really supposed to be like for women. We need you to set the example for us, because we are lost.

Thus, looking at the quest of women's rights organizations for "liberation" of women and gender equality in every aspect of life, raises a number of questions: Is this what our society should aim for? To what extent should society carry out this quest? To give an accurate answer to these questions it is very significant to do research on the subject of "women: education and work." The main objectives of this study are: (1) to reveal and understand the status of women in various civilizations, religions and ideologies, (2) to explore the real status of contemporary women concerning their rights of education and work, (3) to look at the position held by certain world organizations about the emancipation and empowerment women, and (4) to discuss the Islamic perspective towards the rights of women vis-à-vis education and work in light of the concept of gender equality.

The significance of this study is that it presents a clear picture about the status of women concerning their education and work in the perspective of world's civilizations, Western feminist movements and Islam. Descriptive and analytical methods have been employed, as well the comparative method whenever it has been necessary. Data concerning the status of women about their rights of education and work have been collected from various authentic sources. Library 
and online literatures as well the declarations made by different world organizations on women's rights, their emancipation and empowerment, have been the main references. The Qur'Én and the Prophetic Sunnah as well literatures written by contemporary Muslim scholars have been to disclose the Islamic perspective on the subject of "women: education and work.”

\section{The Status of Women in Various Civilizations and Religions}

The status of women in Islam differs from other civilizations, traditions or religions of the world. Islam with its sources, the Qur'Én and the Sunnah of Prophet Muhammad (p.b.u.h.), granted women from the very beginning their respectable status and put them at the same level with men based on their rights, responsibilities and duties. In order for the reader to be able to note the difference that Islam brought to the status of women, a brief look at the attitude of previous civilizations and religions towards this gender would be useful.

In India, women did not have equal rights with their spouses. In most of the cases, a woman was considered the property of her husband. (Werner, 1996, p. 42) Sati/suttee denotes a Hindu practice in India, where a Hindu widow is burned alive with her dead husband or after the death of her husband. In another Hindu practice called Jauhar, a Hindu woman had to burn herself alive before her husband went to battle to protect her honour if he died in the battle. All this was done based on the Hindu belief that men should be accompanied by their wives in the afterlife. (Andrea, 2011, vol. 1, p. 319)

In ancient Greece, men and women were considered as two separate species with two different natures. The great Greek philosopher, Aristotle, said, "...the relation of male to female is that of natural superior to natural inferior, and that of ruler to ruled.” (Reeve, 1998, p. 8) Thus, the male by his nature is superior and ruler of the inferior female. In this sense, women's responsibility is to take care of the house only. (Reeder, 1995, pp. 20-23)

The Romans were not any better than the Greeks in dealing with their women. The Roman women were not allowed to participate in public affairs. They had to devote themselves completely to their husbands. A woman without a husband was seen by the Roman society 
as abnormal. The possibility of prostitution was very high, and she could not be trusted as a witness/a tutor. (Andrea, 2011, pp. 144-145)

In some of the ancient Jewish teachings, women had a low status and they were regarded as inferior creatures compared to man. A woman's rights were limited in various areas. Based on the views of most halakhists "she may not serve as a judge or testify as a witness, and sons precede daughters in inheritance.” (Berlyne, 1996, p. 512) According to the Hebrew Scriptures, the woman was considered as the one who causes all wickedness to man: "Of the woman came the beginning sin and through her we all die." (Ecclesiasticus, 25:24) Initiated by this verse, the Jewish woman in the ancient Jewish society was insulted, mistreated and her position was reduced to a mere slave in the house. (Siddiqi, 1984, p. 9)

In Christianity, as well, little was done to improve the status of women. The first book of the Bible, Genesis, makes Eve responsible for causing Adam's expulsion from the Heavens: "And the man said, the woman whom thou gavest to be with me, she gave me of the tree, and I did eat." (Genesis, 3:12) Christians, hence, regard women as temptresses and as second class human beings. (Britannica, 1984, p. 909) In fact, the early Church Fathers described them as:

the door of hell, as the mother of all human. She should be ashamed at the very thought that she is a woman. She should live in continual penance, on account of the curses she has brought upon the world. She should be ashamed of her dress, for it is the memorial of her fall. She should be especially ashamed of her beauty, for it is the most potent instrument of the demon. (Lecky, 1921, p. 338)

The same attitude and practice prevailed as well in pre-Islamic Arabia, until the advent of Islam. Women were treated unjustly by the Arabs, who considered them as inferior creatures. When a man was blessed with a baby girl, he grieved and his face darkened. (Siddiqi, 1984, p. 14) Some of the Arabs used to bury their daughters alive because the birth of a baby girl was considered as shameful, while some others would bring up their girls in sufferance and contempt. (al-Hatimy, 1983, p. 14) Such situation of the women in the pre-Islamic Arabian society has been mentioned in the following Qur'Énic verses: 
When news is brought to one of them, of (the birth of) a female (child), his face darkens, and he is filled with inward grief! With shame does he hide himself from his people, because of the bad news he has had! Shall he retain it on (sufferance and) contempt, or bury it in the dust? Ah! What an evil (choice) they decide on? (Al-NaÍl: 58-59)

Apparently, through all times and in all civilizations, there was not only a negative attitude towards women, but any disregard, degradation, and insult towards them was considered an acceptable practice and a norm in the society. The Divine teachings of Islam brought a whole new perspective on the treatment and consideration of women that granted them honour and dignity by giving them access to all aspects of life in the society.

The feminist movement made it possible for women to acquire a sense of respect and status in the West. It happened only many centuries later, when "the so-called first wave of the women's emancipation movements and their forerunners," which "covers the period from the Enlightenment and the French Revolution to the First World War," (Paletchek \& Pietrow-Ennker, 2004, p. 3) saw women engaged into some sectors of society, such as, economic, political and educational.

The second wave of feminist movement in the 1970s paved the way for the development of a matured approach and consideration towards the impact of feminist research on education. Therefore, many works were written on the contribution of the feminist on education. The journal of Gender and Education was established in 1989 with the intention to provide a new platform for the feminist educationalists to discuss and analyze various feminist perspectives on education and other disciplines. (Skeleton \& Francis, 2005, pp. 1-3)

Western feminism being a social movement in nature; "has had a profound influence on the daily lives of women and men by challenging patriarchy at every turn” (Pierre \& Pillow, 2000, p. 2). This movement solved many problems related to the role of women outside home's boundaries. In the West, women's inferiority was often due to their physical and biological weakness, as they were weaker, lighter and shorter compared to man. Women's physical weakness was translated as a belief in mental inferiority. Therefore, they were not allowed to 
participate in other aspects of their society expect looking after family. (Simonton, 1998, p. 1) Jennifer L. Martin states:

"Women have made significant social, academic, and occupational gains in the past 50 years; for example, women are entering nontraditional fields with more frequency, participating in high school and college sports more than ever before, and carving out more egalitarian roles for themselves within the family.” (2010, p. 27)

Indeed, the feminist movement in the West stood up for women's rights and responsibilities towards their societies besides their families. The current century has shown that the number of women working as politicians or economists is increasing in all societies and especially in the Western society. For instance, the current Chancellor of Germany, Angela Merkel, has shown to the world that women too have strength and ability to go up to the highest levels of society, like becoming a governor or a politician. In order to make the world a better place to live in, people, regardless of their gender, should think properly about their own innate abilities and strengths on which their personalities stand and not believe in or take blindly what others might say about them.

\section{Women in Education}

In the review of implementation of the Beijing Declaration and Platform for Action, the outcomes of the twenty-third special session of the General Assembly, February 2010, it was stated that the access of women and girls to education of all levels has significantly increased globally. The progress is seen in primary and secondary education, where the ratio has increased "from 92 girls per 100 boys in 1999 to 95 girls per 100 boys in 2006"; and it is even more significant in tertiary education where by 2006 women had "outnumbered men, bringing the proportion to 106 women per 100 men.” (United Nations, 2010, p. 13)

Reflecting on the abovementioned report and the continuous complaints from the women's rights proponents and organizations, one would naturally raise the question: Shouldn't it be men instead of women, who need to start worrying about their own progress related to representation in different levels of education? In this case, the reality and its interpretation show two completely different pictures that make a person to think of the reason behind this continuous dissatisfaction of the feminists. Is it simply the inertia of the past discontents or is 
it the inability of this society to provide non-contradictory guiding principles (derived from the worldview), that can ensure safety, peace, comfort and harmony in the lives of its members? We will come again to this question when discussing the concept of gender equality from the Islamic perspective. For now, let us continue looking at a few more contradictory issues in the writings of Westerners about women's education.

While on the one hand theorists argue that people should be given freedom to choose the area of study where they feel most comfortable and where their potentials lie, the women's rights proponents, on the other hand, complain about women's under-representation in technical or professional courses and programmes, such as Engineering, Agriculture, Veterinary Science and Law, while the enrolment trends in Education, Arts, Science, Medicine and Commerce are positive. (Rehman \& Biswal, 1993, p. 43; Rosser, 2003, p. 24) The Fourth World Conference on Women noted in its document that "girls are still concentrated in a limited number of fields of study." (United Nations, 1996, p. 26) Aiming for equal representation of men and women in all fields of science and technology would probably mean to force women's educational choices towards the needs of the market, disregarding their preferences and even violating their feminine nature. In this way our aims would become unclear. Are we striving for justice or injustice for women?

Another, rather ridiculous, issue related to education of women is the consideration of high fertility rate as an indicator of a country's low level of women's education. Numerous writings list high fertility rate as one of the social ills at a time when many countries are struggling to overcome the negative consequences of population ageing for their society. (Shirahase, 2000, pp. 46-63, and Sleebos, 2003) Often, the examples in this case are taken from the Muslim countries, where traditionally the high number of children is considered a blessing and indicates higher status of the woman and the family.

\section{Islam on Women's Education}

Islam places a strong emphasis on the education of both men and women, who have equal rights to learn, understand and teach. Education in Islam is not seen simply as an instrument for attaining economic power and independence. It is a religious obligation. The more a person 
studies the creation and acquires knowledge, the more he/she becomes conscious of Allah (s.w.t.), the Creator and Sustainer. (Lemu, 1978, p. 252) Indeed, Islam "strongly encourages the education of women both in religious and social domains," which "were regarded as an integral dimension of social development.” (Jawad, 1998, p. 21)

A majority of Muslim scholars agree that the term "Muslim" mentioned in the Qur'Én and the Prophetic Sunnah includes both, men and women. Islam, hence, grants women equal rights of education in order to comprehend their religious and social obligatory duties. (AlSheha, 2000, p. 34) Allah (s.w.t.) says in the Qur’Én:

"Those truly fear Allah, among His servants, who have knowledge.” (FÉl̈ir: 28)

There is no gender discrimination in Islam with regard to intellectual status. Women's education is just as important as men's education. The Qur'Én is full of verses where the learned people, male or female have been praised. They have been encouraged to have original thinking and personal investigation and reject false and barren thinking. The first verse of the Qur'Én commands the Prophet (PBUH) to read (Iqra’):

'Read! In the name of your Lord Who created, created man from clots of congealed blood. Read! Your Lord is the Most Bountiful One, Who taught by the pen, taught man what he did not know’. (al-ÑAlaq: 1-5)

In the above Qur'Énic verse, the Prophet (PBUH) has been told by Allah (s.w.t.) to read, learn, study and understand in the name of Allah (s.w.t.). The message of this verse about how to seek knowledge is applicable to all people regardless of their gender, race, colour, language, and so on. Allah (s.w.t.) gifted man with the ability to write with the pen so that he can develop, educate, preserve and spread the right knowledge from one generation to another.

Prophet Muhammad (PBUH) said: "The search for knowledge is a duty for every Muslim (male and female)”. (Sunan Ibn Majah, ×adêth: 224) This ÍlalÊth shows clearly that the acquisition of knowledge is not meant to be a duty for Muslim men only; rather it is made obligatory upon the Muslim women. Thus, learned Muslim men and women 
were inspired by the Qur’Énic and the Prophetic approaches towards the acquisition of knowledge. They studied, developed and promoted various sciences for centuries prior to the European Enlightenment.

At the beginning of the Islamic era, the focus of most of the academic activities was on the scholarship of ×adÊth and AthÉr. There were a number of women among Prophet (PBUH)'s companions who contributed to the narration and preservation of the Sunnah of the Prophet (PBUH). Moreover, women played an important role in the formation of many Islamic educational institutions. For example, A'ishah (may Allah be pleased with her) contributed significantly to the field of xadÊth, where she is considered as one of the most reliable sources. (Othman, 1989, 155). Her intelligence and outstanding memory made the Prophet (p.b.u.h.) to have advised the Muslims that they could refer to A'ishah (may Allah be pleased with her) for half of their religious instruction. (Lemu, 1978, p. 252)

As maintained by Islam, women constitute a vital segment of communal life, since it is in their hands that the upbringing of the whole society depends on. Therefore, it is necessary that they be taught about all fields of knowledge, without however, violating their feminine nature. Their educational programmes should be "designed according to their specific needs and requirements,” (Maududi, 2000, pp. 121-122) as well as provide the proper guidance they need to efficiently fulfill their responsibilities.

\section{Women at Work}

Although educated women in many countries and regions have outnumbered men, and their academic performance and achievements are generally higher, their level of employment and representation in high office positions is still low as compared to men. ${ }^{3}$ Besides, "while women's access to employment opportunities has increased in recent

3Such phenomenon is supported by: Howie, G. \& Tauchert, A. (eds.), Gender, Teaching and Research in Higher Education, England: Ashgate Publishing, 2002; Luke, C., Globalization and Women in Academia: North/ West - South/East, (NJ, USA: Lawrence Erlbaum Associates Publishers, 2001); Brooks, Ann, Academic Women, UK \& US: The Society for Research into Higher Education \& Open University Press, 1997; and Eggins, H. (ed.) Women as Leaders and Managers in Higher Education, (UK \& US: The Society for Research into Higher Education \& Open University Press, 1997). 
years, women are more likely than men to have low-paid and vulnerable jobs, with limited or no social protection, basic rights or voice at work." (United Nations, 2010, p. 40)

Staying consistent to the framework of this paper, i.e., to reveal what the real picture about the status of women is, how is this picture being interpreted, and how should we look at it from an Islamic perspective, we can say that, although it is not representative of all places and regions, the picture presented is relatively true. What might be questionable and arguable are the reasons behind this representation. The common seal that is placed over all the problems faced by women in the workforce is that of discrimination, which in different writings takes different forms.

For many feminist writers, the main reason that the number of working women is not equal to that of men, is the nature of our male oriented society and "the notion of old boys' club as indicative of larger patriarchal forms of power and control across all sectors of public, and indeed private, life.” (Luke, 2001, p. 209) Thus, according to this view, the low representation of women in the workforce in general, and in high executive positions in particular, occurs simply because they are women and because they are constrained within traditionally defined gender roles. But is this just a question of gender?

Women are created to bear children, and are provided with an innate ability to nurture and care for them, in a way no man can. This has nothing to do with traditions or societal rules. It is a divinely created nature that no one can reasonably argue about. However, if just supposedly, men were to take over these responsibilities, wouldn't we just flip to the other side of the coin, where we would see women outnumbering men and men being underrepresented in the workforce? "Men who bear a major domestic/caring role over a long period also have reduced opportunity for the work that supports promotion.” (Spurling, 1997, p. 39) In that case, we would not benefit anything from the role exchange, but would rather bear the negative social consequences of unattended children and families, because after all, someone has got to do it.

Another reason, given by the literature, for the poor representation of women in the workforce is the underdevelopment of a country and the lack of policies to promote equality and minimize discrimination. However, the voices against women's discrimination are raised more in developed countries like the USA, UK, and Australia. These countries 
report the number of women in various positions as being far from equal compared to that of men. Discussing the inequality issue of women staff in Australian universities Chesterman states:

This inequality is puzzling in light of the fact that Australia has had in place a strong legislative framework that makes discrimination against women and girls unlawful, in both employment and education. Equity legislation was introduced through the 1980s in a number of states. Additionally since 1986, universities in Australia have been covered by the provisions of the federal Affirmative Action (Equal Employment Opportunity for Women) Act... (Chesterman, 2002, p. 236)

These facts speak for themselves that women's representation in the workforce does not depend on the country's development level, nor does it on the enforcement of equality policies. They may suggest that it is simply natural to have lower number of working women as compared to the number of men and that women themselves might choose not to be employed or promoted due to other responsibilities. Indeed, there are many women who do not have ambitions towards employment or career, while seeing the importance of caring for their families. One of the respondents in a study in England states:

[I] found in the end an awful lot of things I was doing weren't satisfying. Being with children - that kind of interpersonal thing - and seeing their progress and their development, that's very important to me. (Pascall \& Cox, 1993, p. 118)

Moreover, "since 1990 it seems that women in Eastern Europe have tended to withdraw more from public life and returned to traditional attitudes towards the place of women in society.” (Kearney, 1996, p.

13) It is, therefore, the choice of these women who have realized that being committed to their responsibility towards the children and family is equally, if not far more, important than a career.

However, if Muslim intellectual women, give priority to their families over their careers, and see themselves as women first and foremost, they are considered as having lower aspirations, and as being neither ambitious, nor competitive with men. Moreover, the traditional values and principles that guide and shape their career motivation and choices are viewed as being a negative influence, even though they admit that these women are "psychologically quite content...not 
disturbed and... [do] not entertain guilt feelings,” (Acar, 1990, p. 140) something that is not found even in Western women who might have achieved their aims in terms of high career positions, but find it hard to develop strategies to cope with role conflict.

Lastly, the blame for the low level of employment of women is put on religions, which are seen by some as a means for subjugating women. According to Rehman and Biswal, "each religion has handed down such traditions and practices for centuries onwards that have successfully helped in perpetuating the idea of gender discrimination against women in innumerable ways and by means of dictate.” (1993, p. 2)

Perception of religions as oppressive would not allow us to see their real role in the status and life of women. What we might have seen throughout the history or in some of the present practices, is a fundamentally distorted understanding of the religious traditions. At the core of almost every religious tradition stands the fact that both men and women are created as human beings and provided with the faculty of intellect.

The universal message of Islam came with a completely different proclamation that treated woman as a human being, with equal rights and responsibilities as man, in the sight of the Creator:

“O Mankind, reverence your Guardian-Lord, Who created you from a single person, created, of like nature, his mate, and from them twain scattered (like seeds) countless men and women.” (Al-NisÉ’:1)

This verse, and many others related specifically to women, is a clear evidence that Islam not only does not oppress women, but gives them rights and a status of respect and dignity that no other religion or civilization has done before.

\section{Islam and Women's Employment}

In Islam, importance is given to women's advanced education, rather than having a career. A Muslim woman is not obliged to work in order to earn her living, because the responsibility to provide maintenance for her is on her father, brother, or husband. Besides, Islam "has added a great value to her natural role as mother and [has] considered it her most sacred and respectable duty.” (WAMY, 1995, p. 31) In this sense, 
an educated woman who might not be officially employed is not seen as lacking in any way because the role of mother and wife is a very essential one for a healthy society.

However, Islam does not prohibit women from seeking lawful employment. They can rightfully earn money and are entitled to whatever they earn. Moreover, they are granted the right to contribute to the well-being of the society and humanity in general. In this way, the society as well, is not restricted from benefiting from their talents. (Al-Hatimy, p. 50)

During the time of Prophet Muhammad (p.b.u.h.), and the years after him, a very considerable number of women have participated in various affairs and contributed to the wellbeing of their society. They have taken part in wars, in medicine, education, and most importantly in the fields of Fiqh and $\times a d \hat{E} t h$. (Al-Hatimy, pp. 51-54) They have played a very important role under the banner of Islam, without however, neglecting their primary role as wives and mothers. The same is expected from any Muslim woman of today.

\section{Gender Equality}

Governments and the international community once more reaffirmed their commitment to the Platform for Action and a common development agenda with gender equality as an underlying principle. (United Nations, 2000)

The unending quest for gender equality has occupied conferences, seminars, talks, researches, books and journals, for the past years and decades. Yet, the commotion has not been able to grant a possible solution to the problem. Thus, several questions arise: Is this society incurably ill? Are we trying to cure a sickness that does not exist, or are we causing the sickness with our remedies? What does equality really mean? Why does a Western woman with a very successful career find contradictions and conflicts between her roles as woman, mother, wife, and careerist? What principles has Islam set that ensure tranquility and contentment and that prevent us from falling into the trap of gender role conflicts?

Aiming for total equality in terms of men's and women's representation in every field of life is simply not natural. It is rather ridiculous to voice out and complain about the fact that in the year 2000, 
"women were $2.7 \%$ of electricians, $1.7 \%$ of carpenters, and $1.2 \%$ of car mechanics” (Sanders \& Tescione, 2002, p. 99). If gender equality would mean a $50 \%$ representation of women in the above fields, it would not only be unnatural and ridiculous, but will also set unrealistic expectations that can never be achieved in real life. Besides, if this goal could be achieved, would it indicate a better society?

In the name of gender equality, the very dignity of the Western women is violated. Only success in performing the functions of men entitles them to honor and respect. To achieve this, they are forced to choose a way of life that does not suit their feminine nature. Yet, they are made to believe that they are the best, ideal model that the other women should follow and aim to reach in order to be counted as developed and civilized. But, does "civilized and successful woman" mean, "I don't cook. I don’t do laundry. I don't market. I don’t take my children to malls and museums and I don't have close friends," "I don't want a family"; or "I don't want to be a wife or a mother"; ultimately, this means "I don't want to be a woman". Does this lifestyle represent for them a worthwhile existence? Or is a society considered to be developed and civilized when its women choose not to have conventional family lives, in favor of their careers? Describing the sample of her study with women in senior posts in higher education, across England and Ireland, Spurling (1997, p. 43) states:

...all had been married at some time; four of the six were separated or divorced; one was married and living with her husband; one was a 'telegamous' marriage, having lived for ten years mostly in a different place from her husband in the interests of her career development...Two had no children one voluntarily. One mother of two children had become a lesbian at the age of $40 \ldots$

The abovementioned statement reveals the real situation of many women especially in England and Ireland. Women's conditions will not be better in countries similar to England and Ireland. If this is the situation of women in most of the developed countries, then, where is

\footnotetext{
4 This is quoted in Fierman, 1992 by Bone, J., in his article "Women and the Ethics of Leadership in Higher Education," in Women as Leaders and Managers in Higher Education, edited by Eggins, H., (UK \& US: The Society for Research into Higher Education \& Open University Press, 1997), p. 25.
} 
the quest for gender equality leading society? It is no wonder that most of these women can find no solution to the gender role conflicts. It is no wonder too, that a great number of Western women have embraced Islam, a religion accused and stereotyped for oppression of women, after getting to know about the true Islam and the status and ultimate respect this system provides for women.

To talk about the concept of gender equality in Islam and to discuss all the instances and evidences where women are granted equal rights with men, would take more than a dissertation. However, for the purpose of this paper we will only speak through two, out of a great number of verses of the Holy Qur'an in this matter:

"Indeed, Muslim men and Muslim women, believing men
and believing women, devoutly obedient men and devoutly
obedient women, truthful men and truthful women, patient
men and patient women, humble men and humble women,
charitable men and charitable women, men and women who
fast, men and women who guard their chastity, and men and
women who remember Allah frequently, for them has Allah
prepared forgiveness and a great reward." (Al-AÍzÉb: 35)

This expressive verse is the divine declaration that renders baseless, false and absurd all the prejudices of discriminatory treatment of women in Islam as well as all the unjust practices in the Muslim world. Being equal in Islam does not mean being identical. Men and women are equally human beings, "have the same status, same dignity, same rights and privileges to exist and operate in this world according to the Divine Commandments. They are subject to the same laws and absolutely equal in the sight of Allah (s.w.t.)." (Farooqui, 2007, p. 224) The fact they are not identical refers to their physical state, as well as their nature, positions and roles that requires rights and duties assigned accordingly. The Qur'Én addresses men and women as each other's garments and protectors:

"They are your garments and ye are their garments." (AlBaqarah: 187)

They should provide for each other mutual support, mutual comfort, and mutual protection, fitting into each other as a garment fits the body. They both are two parts of a system called family and as in a system, each one is equally important for the system's effective functioning. 
This status and treatment granted by a never-changing Divine law would make every woman feel safe, loved and protected. She would be content to be a mother, a wife, and an intellectual, without facing the negative threats of gender role conflicts, because the worldview of Islam provides for her the guiding principles that can help her set the priorities in life.

\section{Conclusion}

The issue of women's discrimination has occupied conferences, seminars, and countless writings in the past few decades. Though the situation is not a positive one in many underdeveloped countries, the voices of complaints have been raised more in developed nations where the progress in gender equality is never enough. Statistics are always presented to argue that women are underrepresented in various fields of education and professions. While many women try to pursue their career, families and children are neglected and left unattended due to failure to set the right priorities. It is, therefore, a personal decision and choice of every woman whether it is worthy to live according to the lifestyle of many Western career women. The issues discussed here are evaluated based on the pure Islamic worldview and not based on the distorted views and practices that occur in many Muslim countries today, which bear the mark of various political agendas and interest groups. However, Muslims are encouraged that the answer to every question and problem, the solution for achieving true freedom, independence, and happiness must come from within, from the depths of the Qur'Én, from the teachings of the Prophet (p.b.u.h.), and from the wealth of the rich Islamic tradition.

\section{References}

Acar, F. (1990). "Role Priorities and Career Patterns: A Cross-Cultural Study of Turkish and Jordanian University Teachers,” in S. S. Lie \& V. E. O’Leary. Storming the Tower: Women in the Academic World. London: Kogan Page \& New York: G P Publishing, 140.

Al-Hatimy, S. A. S. (1983). Woman in Islam: A Comparative Study. Pakistan: Islamic Publications Ltd.

Ali, A. Y.. (1989) The Holy Qur'an: Translation and Commentary. Maryland: Amana Corporation. 
Al-Sheha, A. R.. (2000) Women in Islam and Refutation of Some Common Misconceptions. Abu Salman Deya ud-Deen Eberle (trans.). Abu Ayoub Jerome Boutler Abdurrahman Murada (ed.) Saudi Arabia: Islamic Educational Centre.

Anas bin MÉlik in Sunan Ibn Majah, Book of Sunnah, ×adÊth No. 224.

Aristotle. (1998) Politics I, p. 1254b10. C.D.C. Reeve (trans.). U.S.A.: Hackett Publishing Company.

Baeck, L. (n.d.). Islamic Views on Globalization. Retrieved on February 13, 2015. http://www.planetagora.org/english/theme1_suj5_note.html

Bone, J. (1997). "Women and the Ethics of Leadership in Higher Education," in H. Eggins. Women as Leaders and Managers in Higher Education. UK \& US: The Society for Research into Higher Education \& Open University Press, 25.

Brooks, A. (1997). Academic Women. UK \& US: The Society for Research into Higher Education \& Open University Press.

Budd, K. (n.d.) "Women and Literacy.” 50 th Session Issues, UN. Retrieved on January 28, 2015. http://www.munfw.org/archive/50th/csw1.htm

Cerreti, J. (n.d.) Seeing Muslim Women with Western Eyes. Retrieved on February 18, 2015. http://thefeministwire.com/2012/08/seeing-muslimwomen-with-western-eyes/

Chesterman, C. (2002) "Women's Executive Development in Australian Higher Education,” in G. Howie \& A. Tauchert (eds.). Gender, Teaching and Research in Higher Education. England: Ashgate Publishing, 236.

Eggins, H. (ed.) (1997) Women as Leaders and Managers in Higher Education. UK \& US: The Society for Research into Higher Education \& Open University Press.

Encyclopaedia Britannica. (1984). Vol. 19.

Farooqui, J. (2007) “The Status of Women in Islam: A Sociological Perspective,” inside Proceedings of the International Conference. The Status of Muslim Women in Contemporary Societies: Realities and Prospects, Vol. 7, 2007, IIMU, 224.

Francis, J. (n.d.) Western Perspective. Retrieved on February 18, 2015. https:// www.facebook.com/CometoIslaam/posts/713436472016796

Howie, G. \& Tauchert, A. (eds.) (2002) Gender, Teaching and Research in Higher Education. England: Ashgate Publishing.

Jawad, H. A. (1998) The Rights of Women in Islam: An Authentic Approach. Great Britain: Macmillan Press Ltd. 
Kearney, M-L. (1996). “Women, Higher Education and Development,” in M-L. Kearney \& A. H. Ronning (eds.). Women and University Curriculum: Towards Equality, Democracy and Peace. UNESCO Publishing, 13.

King James Bible - 1611. Ecclesiasticus Chapter 25, Verse 24. Retrieved on February 26, 2015. http://www.kingjamesbibleonline.org/1611-ible/book. php?book=Ecclesiasticus \&chapter $=25 \&$ verse $=24$

King James Bible - 1611. Genesis, Chapter 3, Verse 12. Retrieved on February 26, 2015. http://www.kingjamesbibleonline.org/Genesis-Chapter-3/

Lecky, W.E.H. (1921). History of European Morals from Augustus to Charlemagne. New York \& London: D. Appleton \& Company, Publishers, $3^{\text {rd }}$ Ed., Vol. II.

Lemu, A. (1978). "Women in Islam,” in Altaf Gauhar (ed.) The Challenges of Islam. London: Islamic Council of Europe, 248-267.

Luke, C. (2001) Globalization and Women in Academia: North/West - South/ East. NJ, USA: Lawrence Erlbaum Associates Publishers.

Malti-Douglas, F. (1991) Woman's Body, Woman's Word: Gender and Discourse in Arabo-Islamic Writing. New Jersey: Princeton University Press.

Martin, J. L. (2010). “Gender Differences: The Arguments Regarding Abilities,” in Michele A. Paludi (ed.) Feminism and Women's Rights Worldwide. USA: Praeger, ABC-CLIO, Llc., Vol. 1, 27-42.

Maududi, S. A. A. (2000) The Education. New Delhi: Human Welfare Trust Publications.

Menski, W. (1996) "Hinduism” in Peggy Morgan and Clive Lawton (eds.) Ethical Issues in Six Religious Traditions. U.K.: Edinburgh University Press, 1-54

Othman, M. S. A. (1989) "Status of Women in the Qur'an and the Sunnah.” IIUM Law Journal, 1, 2, 155.

Paletchek, S. \& Pietrow-Ennker, B. (2004) Women's Emancipation Movements in the Nineteenth Century: A European Perspective. Stanford, Calif.: Stanford University Press.

Pascall, G. \& Cox, R. (1993). Women Returning to Higher Education. UK \& US: The Society for Research into Higher Education \& Open University Press.

Pierre, E. A.St. \& P.illow, W. S. (2000) "Introduction: Inquiry among the Ruins," in Elizabeth A.St.Pierre and Wanda S.Pillow (eds.) Working the Ruins: Feminist Poststructural Theory and Methods in Education. New York \& London: Routledge, 1-23. 
Reeder, E. D. (1995) Pandora: Women in the Classical Greece. New Jersey: Prince Town University.

Rehman, M. M. \& Biswal, K. (1993) Education, Work and Women: An Enquiry into Gender Bias. New Delhi: Commonwealth Publishers.

Rosser, S. V. (2003) “Attracting and Retaining Women in Science and Engineering.” Academe, 89:4, 24.

Sanders, J. \& Tescione, S. M. (2002). “Gender Equity and Technology,” in J. Koch \& B. Irby. Defining and Redefining Gender Equity in Education. Connecticut: Information Age Publishing.

Shirahase, S. (2000). "Women's Increased Higher Education and the Declining Fertility Rate in Japan.” Review of Population and Social Policy, 9, 47-63.

Siddiqi, M. I. (1984) The Family Laws of Islam. Pakistan: Kazi Publications.

Simonton, D. (1998) A History of European Women's Work: 1700 to the Present. London \& New York: Rutledge.

Skelton, C. \& Francis, B. (2005) “Introduction,” in Christine Skelton \& Becky Francis. A Feminist Critique of Education: 15 Years of Gender Education. London \& New York: Rutledge Taylor and Francis Group, 1-8.

Sleebos, J. E. (2003) “Low Fertility Rates in OECD Countries: Facts and Policy Responses.” OECD Social Employment and Migration Working Papers. Retrieved on January 16, 2015. http://www.oecd-ilibrary.org/docserver/ download/fulltext/5lgsjhvj7qg7.pdf?expires=1324878949\&id=id\&accna me=guest\&checksum=42B378AC08E71FD243B43FDE94B4E6B2

Spurling, A. (1997). "Women and Change in Higher Education,” in H. Eggins (ed.). Women as Leaders and Managers in Higher Education. UK \& US: The Society for Research into Higher Education \& Open University Press.

The Encyclopedia of Jewish Life and Thought. (1996) Alex Berlyne (ed.) Israel: Carta Jerusalem.

United Nations (1996) Report of the Fourth World Conference on Women, Beijing, 4-15 September 1995. United Nations-New York. Retrieved on February 13, 2015. http://www.un.org/womenwatch/daw/beijing/pdf/ Beijing\%20full\%20report\%20E.pdf

United Nations (2000). Five-year Review of the implementation of the Beijing Declaration and Platform for Action (Beijing + 5) held in the General Assembly, 5 - 9 June 2000. Retrieved on March 10, 2015. http://www. un.org/womenwatch/daw

United Nations (2010) Economic and Social Council. Retrieved on February 16, 2015. http://www.pes.org/fr/system/files/UN-doc-PES-Women.pdf

United Nations. (1996). Report of the Fourth World Conference on Women, Beijing, 4-15 September 1995. United Nations-New York. Retrieved 
on January 15, 2015.http://www.un.org/womenwatch/daw/beijing/pdf/ Beijing\%20full\%20report\%20E.pdf

United Nations. (2010). Economic and Social Council. Retrieved on February 13, 2015. http://www.pes.org/fr/system/files/UN-doc-PES-Women.pdf

WAMY (1995). Woman and Family Life in Islam, paper presented at the UN Conference on Women, Beijing. WAMY: Saudi Arabia.

Women in Ancient Greece. (n.d.) Retrieved on February 23, 2015. http://www. historymuseum.ca/cmc/exhibitions/civil/greece/gr1100e.shtml

World History Encyclopedia. (2011) Alfred J. Andrea (ed.). USA-CaliforniaSanta Barbara: ABC-CLIO, LLC, Vol. 5.

World History Encyclopedia. (2011). Alfred J. Andrea (ed.). USA-CaliforniaSanta Barbara: ABC-CLIO, LLC, Vol. 1. 